\title{
The Comparison of Business Regulations in Czech and Malaysian Economies in 2020
}

\author{
Eva HAMPLOVÁ 1,*, Raihan MASKURIY ${ }^{2}$ and Wan Nur Hidayah IBRAHIM ${ }^{2}$ \\ 1 University of Hradec Kralove, Hradec Kralove, Czech Republic; eva.hamplova@uhk.cz \\ 2 University Teknologi Malaysia , Kuala Lumpur, Malaysia; raihan.maskuriy@gmail.com; \\ wannurhidayahibrahim@gmail.com \\ * Correspondence: eva.hamplova@uhk.cz
}

\begin{abstract}
The paper compares the present business circumstances that the International Bank for Reconstruction and Development evaluates for the last 17 years annually. The data acquired from this data set are further analyzed in order to obtain insight into similarities and differences of the business regulation in selected economies with dissimilar political, cultural, historical and territorial background, completely different sizes and populations. Czech and Malay economies are assessed on the basis to 10 criteria selected from a very wide range of areas that clearly contribute to the quality of the business environment. The data were collected for the period between May 2018 and May 2019. The analysis shows that the Czech Republic and Malaysia have not similar business regulation, completely different position in the ranking of surveyed countries. This contribution uses data from the October report called Doing Business 2020. A more detailed assessment of individual subsections shows a significant difference in protecting minority investors, dealing with construction permits for business purposes, in trading across borders and differences in legal enforcement of valid contracts.
\end{abstract}

Keywords: Doing Business 2020; entrepreneurship; business environment; business regulation

JEL Classification: L25; L26; O10

\section{Introduction}

Business environment and the comparison of business conditions is an important parameter of macroeconomic stability and an important determinant of economic growth (Commander and Svejnar 2011), (Korner et al. 2002) and (Odehnal and Michalek 2011). The impact of the macroeconomic business environment on the development of corporate social responsibility has been examined by (Hategan et al. 2018), (Krajnakova 2018). These authors have found out that the business environment can affect corporate social responsibility in a variety of ways, and even in unfavourable macroeconomic conditions, companies continue to participate in socially responsible activities due to the fact that they bring them long-term benefits. In order to verify this statement, a quantitative assessment of the quality of institutions is needed. The importance of business environment has been evaluated in other articles by other authors, for example (Carmeli 2001), (Slavik and Jurikova 2002), (Petrik 2001), (Klapper and Parker 2011), (Chavis et al. 2011) and (Young 2001).

This paper explores the International Bank for Reconstruction and Development studies, especially the last one from 2019, which focuses on defining individual aspects of the quality of the business environment worldwide. In particular, we will focus on assessing the conditions for doing business in Malaysia and the Czech Republic.

Business conditions in various countries have been assessed for the last 17 years by World Bank Group and International Bank for Reconstruction. Then, the results are made public in final reports named "Doing Business" (DB 2019). The study affords quantitative indicators containing 12 sections of the business environment in 190 economies. The goal of the periodical studies is to afford objective data for practice by governments in proposing to publish business regulatory policies and to advance study on the important topics of the regulatory surroundings for companies. The yearbook Doing Business 
2020 is the 17th in sequences of summary exploring the rules that magnify enterprise activity and those that confine it.

\section{Methodology and Procedure for Assessing the Quality of Business Environment}

The current report compares business regulations and rules in 190 countries around the world practicing 12 main indices. The overall indicator ranks each compared country in the global ranking like the result of the average value of only 10 indicators. The total overview completes further 7 territorial groups (32 OECD high income countries, 25 from East Asia \& Pacific, 25 from Europe \& Central Asia, 8 from South Asia, 32 from Latin America \& Caribbean, 19 from Middle East \& North Africa, 49 from Sub-Saharan Africa).

Doing Business presented progress in the last few years to all its index groups. In the 2015 yearbook, the existing measures of Protecting Minority Investors and Getting Credit were broadened, while Resolving Insolvency introduced new measures of quality. In the yearbook Doing Business 2016, a new case scenario was introduced by Trading across Borders with the intention to raise the relevance of economy and index groups of Enforcing Contracts, Getting Electricity, Registering Property and Dealing with Construction Permits presented new quality measures as well. Doing Business 2017 yearbook contains the addition of gender components by Enforcing Contracts, Registering Property and Starting a Business and new measures of post filing processes introduced by Paying Taxes.

Calculation of scorings is only available for the Doing Business 2020 annual report. The comparability of the prior years is influenced by year-to-year changing numbers of economies, indicators and methodology. The recalculation of each methodology extension for one year took place in order to give corresponding index values and ranking for the previous year. The data which were obtained from Doing Business 2020 study cover two following areas:

- AREA I. Indicators characterizing the complexity and cost of regulatory processes in the monitored country in the form of an assessment:

- Starting a Business,

- Dealing with Construction Permits,

- Getting Electricity,

- Registering Property,

- Paying Taxes and

- Trading Across Borders.

- AREA II. Indicators characterizing the strength of legal institutions in the monitored country, namely:

- Getting Credit,

- Protecting Minority Investors,

$\circ \quad$ Enforcing Contracts and

$\circ$ Resolving Insolvency.

Within the monitored areas, the indicators are evaluated according to 3-6 additional sub-criteria, which ensures the objectivity of the evaluation and, in particular, the expertise because all individual assessments are done by competent auditing and legal offices in each country. Each of the 10 indicators has the same weight in the overall rating, but it does not mean that the country ranked first in the overall rankings ranks first in sub-ratings. What is important is the average placement of the country according to all individual sub-areas.

\section{Ease of Doing Business Ranking and Ease of Doing Business Score Results}

The comparison of countries shown in the ease of doing business (EODB) ranking is done with regard to regulatory best practice; countries are benchmarked to each other in the ease of doing 
business score, indicating the entire range to the top regulatory performance on each Doing Business index. In this range, the topmost record is the example of the best regulatory achievement on the indicator among all the countries since 2005 or the third year when data for the index were processed.

When the analysis over years is carried out, the ease of doing business ranking shows, how much a country's administrative climate for local entrepreneurs has changed over time in absolute values, while in the ease of doing business ranking only the amount of administrative climate transformation in relation to other countries can be presented. The very top countries in the ease of doing business list (see Tab. 1) are those with permanently well-created business climate or those having favourable administrative surroundings due to extensive enhancement throughout the years. The five highest ranking economies of this year - New Zealand, Singapore, Hong Kong, Denmark and Korea Republic - represent a business-friendly climate and they have been leading the ranking since 2010.

\subsection{Ease of doing business ranking overview}

Table 1. Ease of doing business ranking - TOP 12 (DB, 2019).

\begin{tabular}{|c|c|c|c|c|}
\hline Rank & Economy & Region & $\begin{array}{l}\text { EODB } \\
\text { score } \\
(2020)\end{array}$ & $\begin{array}{l}\text { EODB score } \\
\text { change } \\
(2020 / 2019)\end{array}$ \\
\hline 1 & New Zealand & OECD high income & 86.8 & -0.02 \\
\hline 2 & Singapore & East Asia \& Pacific & 86.2 & +0.4 \\
\hline 3 & Denmark & OECD high income & 85.3 & +0.1 \\
\hline 4 & Hong Kong SAR China & East Asia \& Pacific & 85.3 & +0.2 \\
\hline 5 & Korea Rep. & OECD high income & 84.0 & 0.0 \\
\hline 6 & United States & OECD high income & 84.0 & $+0,4$ \\
\hline 7 & Georgia & Europe \& Central Asia & 83.7 & +0.2 \\
\hline 8 & United Kingdom & OECD high income & 83.5 & -0.1 \\
\hline 9 & Norway & OECD high income & 82.6 & -0.3 \\
\hline 10 & Sweden & OECD high income & 82.0 & 0.0 \\
\hline 11 & Lithuania & Europe \& Central Asia & 81.6 & +0.6 \\
\hline 12 & Malaysia & East Asia \& Pacific & 81.5 & +0.2 \\
\hline$:$ & $:$ & & & \\
\hline 40 & Poland & OECD high income & 76.4 & -0.5 \\
\hline 41 & Czech Republic & OECD high income & 76.3 & 0.0 \\
\hline 45 & Slovak Republic & OECD high income & 75.6 & +0.2 \\
\hline 52 & Hungary & OECD high income & 73.4 & +0.2 \\
\hline
\end{tabular}

${ }^{1}$ Notes: The range from 1 to 190 is captured by the ease of doing business ranking. The ease of doing business score shows the gap in each economy from the highest regulatory performance monitored on each of the indicators across all economies in the Doing Business sample since 2005. The position on the scale from 0 to 100 reflects an economy's ease of doing business, where 0 means the lowest and 100 the highest performance.

\subsection{Malaysia and the Czech Republic - details of Doing Business conditions}

The evaluation of the situation in the countries under review is shown in Table 2. In terms of complexity and cost of regulatory processes, three out of six indicators in Malaysia are clearly better evaluated than in the Czech Republic, while the remaining three are better in the latter. Malaysia is much better rated in dealing with building permits. Malaysia scores higher than the OECD average or the East Asia Pacific region in this assessment, mainly due to the very low number of days and procedures to build a warehouse. Procedure is any interaction between the managers or employees of 
a company and external parties. There are only insignificant differences in other sub-indicators. The costs are a percentage of the value of the warehouse and the quality assurance index based on six other indices - quality assurance after construction, quality assurance during construction, quality assurance before construction, quality of building regulations, liability and insurance regimes and indices of professional certification.

On the contrary, the Czech Republic is significantly better than Malaysia in Trading across borders. The Czech Republic receives a better score than the OECD average, East Asia \& Pacific area as well. It is the recording of time and costs associated with the logistics process for exporting and importing goods, time and cost measurement associated with the following procedures - national transport, border compliance, and document compliance - as part of the overall process of shipment, import and export of goods. Although the database contains and reports data on time and cost of local transport, it is not used to calculate the index of cross-border trading or assess its ease. The main point is that local transport time and costs are affected by many external factors. Among them, the topography, geography, and general infrastructure of the transit area, the location of warehouses where goods are kept, road capacity and proximity to the nearest port or border. Therefore, they are not directly influenced by trade policies and economic improvements of the country in question.

Table 2. Complexity and cost of regulatory processes (DB 2019).

\begin{tabular}{|c|c|c|c|c|c|c|}
\hline \multirow[t]{2}{*}{ Topic and indicator } & \multirow[t]{2}{*}{ Malaysia } & \multirow[t]{2}{*}{$\begin{array}{l}\text { Czech } \\
\text { Republic }\end{array}$} & \multicolumn{2}{|c|}{$\begin{array}{l}\text { East Asia \& } \\
\text { Pacific/OECD high } \\
\text { income countries }\end{array}$} & $\begin{array}{l}\text { EODB } \\
\text { score } \\
\text { Malaysia }\end{array}$ & $\begin{array}{l}\text { EODB } \\
\text { score } \\
\text { Czech }\end{array}$ \\
\hline & & & & score & & Republic \\
\hline Starting a business & & & & $83.9 / 91.3$ & 83.3 & 82.1 \\
\hline & & & & & (126) & (134) \\
\hline Procedures (number) & $8(9)$ & 9 & $6.5(6) / 4.9$ & & & \\
\hline Time (days) & $17(18)$ & 24.5 & $25.6(7) / 9.2$ & & & \\
\hline Cost (\% of income per capita) & 17.4 & 1.1 & 3.0 & & & \\
\hline $\begin{array}{l}\text { Minimum capital (\% of income } \\
\text { per capita) }\end{array}$ & 0.0 & 0.0 & $3.5 / 7.6$ & & & \\
\hline Dealing with construction & & & & $70.0 / 75.6$ & 89.9 & 56.20 \\
\hline permits & & & & & (2) & (157) \\
\hline Procedures (number) & 9 & 21 & $14.8 / 12.7$ & & & \\
\hline Time (days) & 41 & 246 & $132.3 / 152.3$ & & & \\
\hline Cost (\% of warehouse value) & 1.3 & 0.2 & $3.2 / 1.5$ & & & \\
\hline $\begin{array}{l}\text { Building quality control index } \\
(0-15)\end{array}$ & 13 & 8.0 & $9.4 / 11.6$ & & & \\
\hline Getting electricity & & & & $75.1 / 85.9$ & 99.3 & 95.6 \\
\hline & & & & & (4) & (11) \\
\hline Procedures (number) & 3 & 3 & $4.2 / 4.4$ & & & \\
\hline Time (days) & 24 & 58 & $63.2 / 74.8$ & & & \\
\hline Cost (\% of income p.c.) & 25.6 & 23.1 & $594.6 / 61.0$ & & & \\
\hline $\begin{array}{l}\text { Reliability of supply and } \\
\text { transparency of tariffs index (0-8) }\end{array}$ & 8 & 8 & $4.0 / 7.4$ & & & \\
\hline
\end{tabular}


Table 2. Complexity and cost of regulatory processes (continued)

\begin{tabular}{|c|c|c|c|c|c|c|}
\hline \multirow[t]{2}{*}{ Topic and indicator } & \multirow[t]{2}{*}{ Malaysia } & \multirow[t]{2}{*}{$\begin{array}{l}\text { Czech } \\
\text { Republic }\end{array}$} & \multicolumn{2}{|c|}{$\begin{array}{l}\text { East Asia \& } \\
\text { Pacific/OECD high } \\
\text { income countries }\end{array}$} & $\begin{array}{l}\text { EODB } \\
\text { score } \\
\text { Malaysia }\end{array}$ & \multirow{2}{*}{$\begin{array}{l}\text { EODB } \\
\text { score } \\
\text { Czech } \\
\text { Republic }\end{array}$} \\
\hline & & & \multicolumn{3}{|c|}{ score } & \\
\hline & & & & $57.5 / 77.0$ & 79.5 & 79.7 \\
\hline 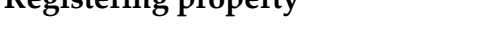 & & & & & (33) & (32) \\
\hline Procedures (number) & 6 & 4 & $5.5 / 4.7$ & & & \\
\hline Time (days) & 11.5 & 27.5 & $71.9 / 23.6$ & & & \\
\hline Cost (\% of property value) & 3.5 & 4.0 & $4.5 / 4.2$ & & & \\
\hline $\begin{array}{l}\text { Quality of land administration } \\
\text { index }(0-30)\end{array}$ & 26.5 & 25.0 & $16.2 / 23.2$ & & & \\
\hline Daxing taum & & & & $73.6 / 84.3$ & 76.0 & 81.4 \\
\hline 1 aymg laxes & & & & & $(80)$ & (53) \\
\hline Payments (number per year) & 9 & 8 & 20.6/10.3 & & & \\
\hline Time (hours per year) & 174 & 230 & $173 / 158.8$ & & & \\
\hline $\begin{array}{l}\text { Total tax and contribution rate ( } \% \\
\text { of profit) }\end{array}$ & 38.7 & 46.1 & 33.6/39.9 & & & \\
\hline Postfiling index (0-100) & 51.0 & 90.5 & $56.4 / 86.7$ & & & \\
\hline Trading across borders & & & & $71.6 / 94.3$ & $\begin{array}{l}88.50 \\
(49)\end{array}$ & $\begin{array}{l}100.00 \\
\text { (1) }\end{array}$ \\
\hline Time to export I import: Border & $28 \mid 36$ & $0 \mid 0$ & $57.5 \mid 68.4 /$ & & & \\
\hline compliance (hours) & & & $12.7 \mid 8.5$ & & & \\
\hline Cost to export limport: Border & $213 \mid 213$ & $0 \mid 0$ & $281.1 \mid 422.8 /$ & & & \\
\hline compliance (USD) & & & $136.8 \mid 98.1$ & & & \\
\hline Time to export / import: & $10 \mid 7$ & $1 \mid 1$ & $55.6|53.7|$ & & & \\
\hline Documentary compliance (hours) & & & $2.3 \mid 3.4$ & & & \\
\hline
\end{tabular}

The assessment of the situation of the monitored countries shows the following results (see Table 3). Concerning the strength of legal institutions, three of the four indicators are clearly in favor of Malaysia, whereas the remaining one is better in case of the Czech Republic. Malaysia is doing significantly better in Protecting Minority Investors, Enforcing Contracts and Getting Credit. The fourth sub-indicator - Resolving Insolvency - is favorable for the Czech Republic. The data is derived from a questionnaire collected by company and securities lawyers and is based on company law, civil code of law, court rules of evidence and the disposition of securities. Protection of minority investors helps prevent conflicts of interest by means of a set of indices. These scores are the sum of the extent of conflict of interest regulation index and the extent of shareholder governance indicator. The indicator called Enforcement Contract measures the cost and time of needed to solve commercial disputes by local courts of first instance and the index of quality of litigation. It also assesses whether or not the country in question has adopted best practices supporting the quality and efficiency of the justice system. 
Table 3. Strength of legal institutions (DB 2019).

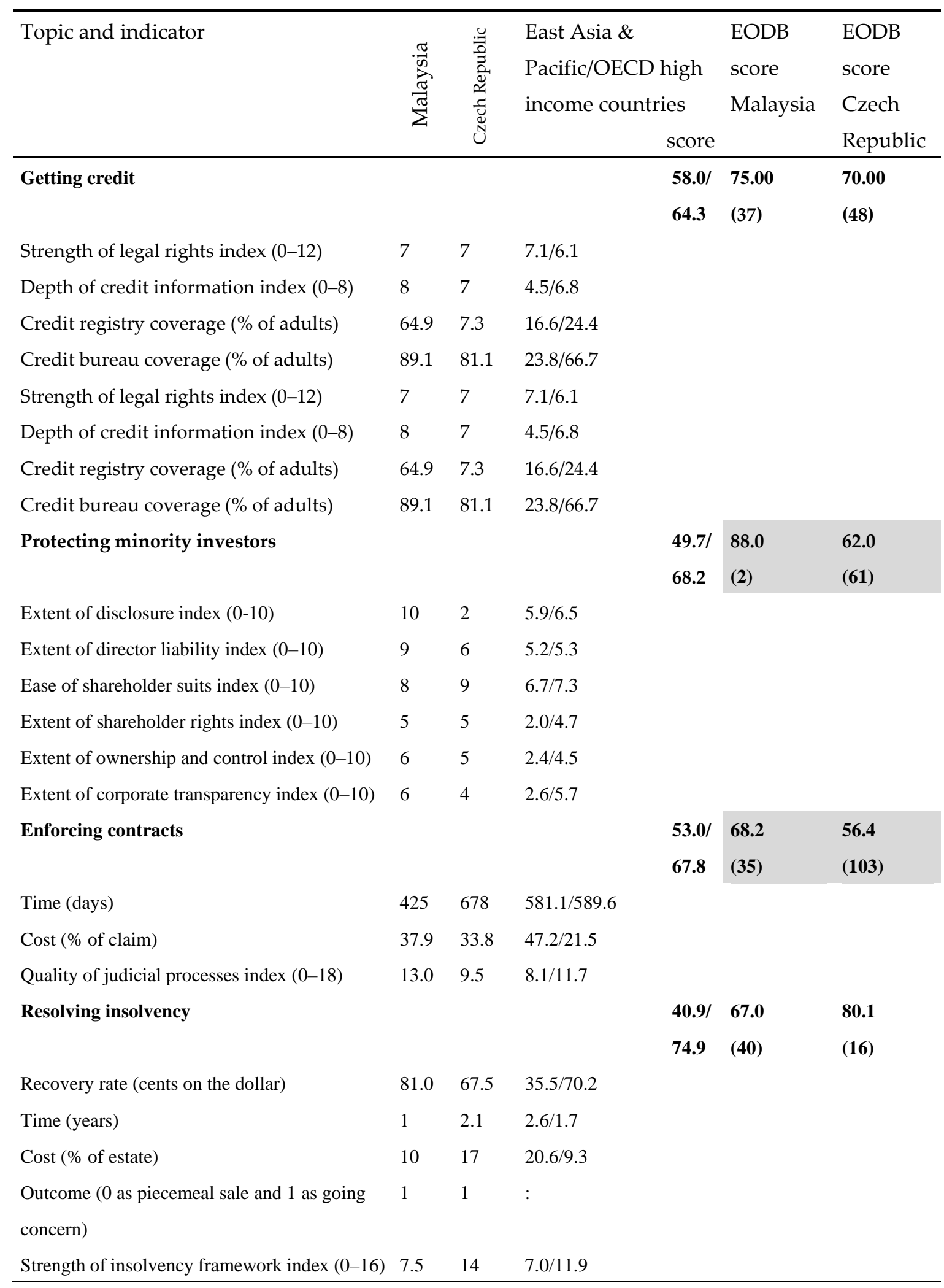

The Resolving insolvency category is a weak point in evaluating business conditions in Malaysia. It is measured the time, cost and outcome of insolvency proceed-ings involving domestic entities as well as the strength of the legal framework applicable to judicial liquidation and reorganization proceedings. Data for solving insolvency indicators are derived from the replies to questionnaire created by local insolvency trustees and verified by studying laws and regulations as well as 
public information on insolvency systems. The ranking of countries according to the ease of solving insolvency is determined by classifying their score for solving insolvency. The indicator is counted simply as an average of the score of Recovery Rate and Strength of Insolvency Framework Score.

\section{Discussion}

This paper focuses on the assessment of business conditions published by the International Bank for Reconstruction and Development this year. This institution has been evaluating the conditions for doing business in 10 different areas according to a very sophisticated methodology for 17 years. The authors' interest was to compare the conditions for doing business in Malaysia and the Czech Republic. These countries have a very different history, politics and culture. Nonetheless, the basic dissimilarity are their respective areas and populations. Malaysia is four times larger and has nearly 3 times more inhabitants. Malaysia ranked 12th and Czech Republic 41st among 190 countries.

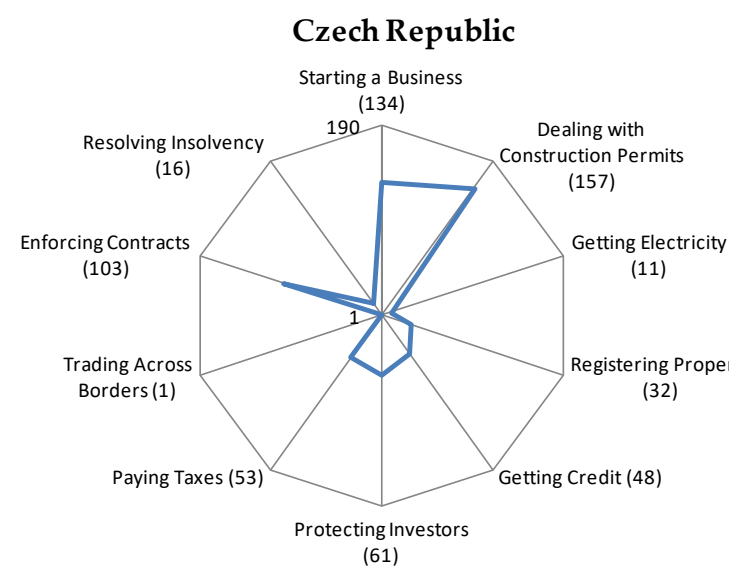

(61)

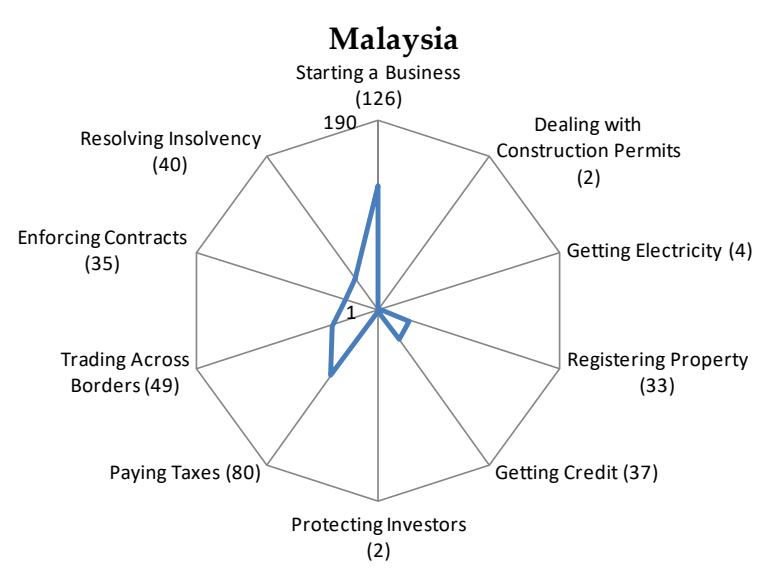

(2)

Figure 1. Similarities and differences of the business regulation between the Czech Republic and Malaysia.

It is clear that the conditions for doing business in both countries are different, but there are some similarities and in some areas Malaysia has its weaknesses. In the overall evaluation, criteria relating to the complexity and cost of regulatory processes are analyzed first, followed by criteria relating to the strength of legal institutions. The complexity and cost of regulatory processes are defined by 6 indicators. There is the only indicator of business conditions that both these countries have identical, that is Registering Property.

Differences are evident in the indicators Dealing with Construction Permits, Starting a Business and Getting Electricity. Establishing your own company in the conditions of the Malaysian economy is easier than in the Czech economy, but due to a large number of procedures, days and, ultimately, costs, the establishment of a company in both countries is very difficult. The fundamental difference between the two economies can be seen in the indicator Dealing with Construction Permits. This indicator clearly shows the very low number of procedures required to obtain a building permit, thus reducing the time required for it. The differences between the two economies are so significant that Malaysia is in this respect gaining a significant advantage over the Czech Republic in the overall ranking. Malaysia is better ranking in the area of Getting Electricity. On the other hand, the Czech Republic boasts of better conditions for doing business in the areas of Paying Taxes or Trading Across Borders. Still, even these advantages cannot move the Czech economy among the top 40 economies. In the second important area of evaluation - Strength of Legal Institutions - almost all criteria are evaluated in favor of Malaysia. Enforcing Contracts, Getting Credit and especially Protecting Minority Investors are areas where Malaysia is gaining a significant advantage over the Czech 
Republic thanks to the strength of its legal institutions. Only one area out of four resulted in favor of the Czech Republic, namely Resolving Insolvency.

Malaysia has been continuously improving its Doing Business rankings over the past three years through its reforms. It was during these years that it carried out nine major reforms. For instance, in 2019 Malaysia streamlined the process of Dealing with Construction Permits by eliminating the road and drainage inspection performed by Kuala Lumpur City Hall. In 2018, Malaysia made starting a business easier by introducing an online registration system for goods and service tax. Unfortunately, the position of the Czech Republic has been declining over the past three years. The position of the Czech Republic in the Doing Business 2020 study is worst in seven years. The last reform that could have had a positive effect, took place in 2017 - the Czech Republic made starting a business less expensive by introducing lower fees for simple limited liability companies. Unfortunately, the positive effect was ruined by the measure whereby the Czech Republic made paying taxes more complicated by introducing new requirements for filing VAT control statements. Reforms that would simplify doing business and make it more efficient are not detected in the Czech economy. This is a major problem and this situation has clearly manifested itself in the current ranking of the Czech economy among all the evaluated economies of the world.

Acknowledgments: This study is supported by internal research project "Investment evaluation within concept Industry 4.0" at Faculty of Informatics and Management, University of Hradec Kralove.

\section{References}

Doing Business 2020. 2019. Available online: https://openknowledge.worldbank.org/bitstream/handle/10986/ 32436/9781464814402. pdf (accessed on 12012020).

Carmeli Abraham. 2001. High- and low-performance firms: do they have different profiles of perceived core intangible resources and business environment? Technovation: 21(10), 661-671. https://doi.org/10.1016/S0166-4972(01)00050-5.

Chavis W. Larry, Klapper F. Leora, and Love Inessa. 2011. The Impact of the Business Environment on Young Firm Financing. World Bank Economic Review: 25(3), 486-507. https://doi.org/10.1093/wber/lhr045.

Commander Simon, and Svejnar Jan. 2011. Business environment, exports, ownership, and firm performance. Review of economics and statistics: 93(1), 309-337. https://doi.org/10.1162/REST_a_00135.

Hategan Camelia-Daniela, Sirghi Nicoleta, Curea-Pitorac Ruxandra-Ioana, and Hategan Vasile-Petru. 2018. Doing Well or Doing Good: The Relationship between Corporate Social Responsibility and Profit in Romanian Companies. Sustainability: 10(4), Nr. 1041. https://doi.org/10.3390/su10041041.

Klapper F. Leora, and Parker C. Simon. 2011. Gender and the Business Environment for New Firm Creation. World bank research observer: 26(2), 237-257. https://doi.org/10.1093/wbro/lkp032.

Koerner Peter, Kudrna Zdenek, and Vychodil Ondrej. 2002. Measuring business environment quality in Central Europe. Finance a úvěr: 52(12), 674-697.

Krajnakova Emilia, Navickas Valentinas, and Kontautiene Rima. 2018. Effect of macroeconomic business environment on the development of corporate social responsibility in Baltic Countries and Slovakia. Oeconomia Copernicana: 9(3), 477-492. https://doi.org/10.24136/oc.2018.024.

Odehnal Jakub, and Michalek Jaroslav. 2011. An empirical analysis of the business environment of selected european union regions. Politicka ekonomie: 59(2), 242-262. https://doi.org/10.18267/j.polek.783.

Petrik Borislav. 2001. The formation of the business environment, its problems and outlooks. Ekonomicky casopis: 49(3), 527-538.

Slavik Stefan, and Jurikova Benita. 2002. Variability and complexity of Slovak business environment (external conditions for uprise of a competitive advantage). Ekonomicky casopis: 50(2), 217-234.

Young Stephen. 2001. What do researchers know about the global business environment? International marketing review: 18(2), 120-129. https://doi.org/10.1108/02651330110389963. 